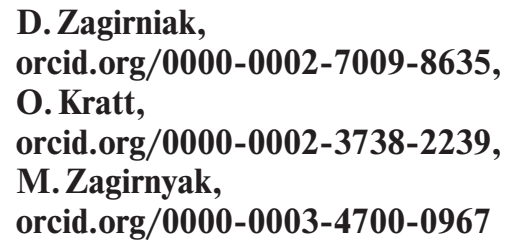

\title{
RATIONALIZATION OF THE CHOICE OF PROFESSIONAL EDUCATION IN THE CONTEXT OF THE NEEDS OF BUSINESS ENVIRONMENT
}

Purpose. Rationalization of the person's choice of the HE in relation to the personnel needs of the branch business environment based on determining the number of positions and staff units by educational degree in the branch directory of specialties.

Methodology. The method of rational choice of the future profession by a potential consumer of educational services (taking Mining specialty as an example), based on the parameterization of professional and qualification needs of mining enterprises as the subjects of the branch business environment.

Findings. Methodical recommendations on the professional orientation of the individual in the context of the needs of the branch business environment (mining enterprises) have been formed. The low level of educational pragmatism in the behavior of educational service consumers is explained by the lack of professional experience. When choosing a profession, applicants focus on the specialties offered by educational standards rather than the needs of employers. In particular, staffing of mining enterprises reflects the qualitative and quantitative composition of the professional and qualification needs of employers, recorded in job descriptions. The methodical recommendations are in the form of a Directory that contains qualitative (specialty) and quantitative (staff units) aspects of the mining industry's impersonal staffing needs, allowing employers to influence prospective students' consumer preferences as to future employment, vocation and qualification characteristics. This, on the one hand, will greatly improve the professional orientation of the person, and, on the other hand, will release the personnel needs of the mining industries as the basis of Ukrainian business environment to public.

Originality. Rationalization of qualitative the individual's choice of higher education and the most useful profession for future employment due to releasing and quantitative aspects of the personnel needs of the mining industry to public in the Directory of specialties.

Practical value. Public consolidation of the personnel needs of mining companies in the Directory of specialties required in the branch labor market allows employers to influence effectively the choice of potential consumers of professional educational services in Mining.

Keywords: higher education, mining, extractive sector, employers' needs

Introduction. At present, higher education institutions (hereinafter referred to as HEI) and vocational technical educational establishments (hereinafter referred to as VTEE) make every effort to ensure that the potential consumer makes the choice in favor of their educational services. The conviction of institutions in the truth of their arguments and pedagogical skill determine the consumer choice. In these circumstances, the institutions do not help the individual, but directly choose a specialty and educational degree instead. In most cases, however, neither HEI nor VTEE are responsible for the employment of graduates. Higher education (hereinafter referred to as HE) reform has increased the imbalance of supply and demand in the branch labor markets, particularly in the mining industry. The reorientation of consumer choice of HE towards economic interests has led to the situation in which young people chose occupations that represented commercial success. Therefore, despite the fact that the mining industry was and remains the basic branch of Ukrainian economy, the interest of young people to choose engineering professions has decreased. However, economic interest is realized due to employment, that is, to meeting the real needs of employers in the mining industry. The pragmatism of the consumers of professional educational services has proved that professional knowledge, and skills are not fully required in the in-house labor market of mining enterprises. Therefore, there is no link between consumer choice and the personnel needs of the branch labor market. The link is possible through a tool that identifies the parameters of HE demand with employers' needs.

Literature review. Orientation of the person's choice of $\mathrm{HE}$ to the needs of the employers is no more than a declaration, if there is no tool to make it a reality. Bussmann S. and Seyda S. identify the tools for solving the deficits of certain professions

(C) Zagirniak D., Kratt O., Zagirnyak M., 2020 in Germany [1]. The principle of action is the basis of any tool. The pragmatism of consumer choice in HE is based on experience. However, a young person who chooses a professional future does not have professional experience, which prevents pragmatic behavior. The problem is solved by the rational choice, which is popular with Western HE researchers. In this regard, Berger J. and Offe C. argue that the truth of the laws of the movement of the capitalist mode of production is proven by the experience of modern capitalism, but one should not avoid analysis based on the paradigm of rational choice (Berger, J., Offe C., 1982). Revealing aspects of rationality, Nickerson R. mentions education in the context of didactics 65 times (Nickerson R. S., 2008). Domper K. takes into account the fact that many values of rationality give rise to many aspects of its definition (Domper K. K., 2009). Murphy M. defines the boundaries of bureaucracy, comparing accountability and rationality in HE (Murphy M., 2009). Stenmark M. criticizes models of rationality in science, religion, and everyday life (Stenmark M., 1995). Putnam H. compares rationalism in decimates the choice of HE with rationality (Richards M., 1973). More than ten years ago, Ukrainian scientists, Kratt O. and Deieva L., tried to introduce elements of rationality into the activities of higher education (Kratt O.A., Deieva L. H., 2008). At the same time, the utilitarian purpose of the tool as a set of methodical and technical methods, techniques and means of orienting consumer choice of $\mathrm{HE}$ for employers' needs is giving way to a methodological one, which achieves the combination of interests of the individual, business and educational institution. This paper deals with a methodological tool.

Purpose. Rationalization of the person's choice of the HE in terms of personnel needs of the mining enterprises based on determining the number of positions and staff units by educational degree in the branch directory of specialties. 
Results. Choosing the services of HE, considering the scale and duration, is an economic phenomenon of the microlevel, since it affects the interests of the individual and the HEI, and therefore, the rationality is its basis. The latter adds to the choice of targeting, which is related to the specialty and educational degree (hereinafter - ED: junior specialist (js), bachelor $(b)$, master $(m))$ as the basis of future profession and qualification. If the state influences the choice of HE, the Ukrainian business as a consumer of professional qualifications of the future employee does not influence the choice. This thesis is confirmed by the annual enrollment in the specialty "Mining" in the HEI of Ukraine [2].

Enrollment in the specialty based on complete comprehensive secondary education (hereinafter - CCSE) is reflected by the following indicators: licensed scope (hereinafter referred to as LS); the number of submitted applications (hereinafter - SA); the number of persons enrolled at the expense of the state budget (hereinafter - EB); the number of persons enrolled by the contract (hereinafter - the EC).

In 2019, nine HEIs provided training in the "Mining" specialty according to ED $b$. Table 1 contains indicators characterizing the enrollment in "Mining" specialty according to ED $b$ and the forms of training based on CCSE in 2019 [3].

In Table 1 the total number of the submitted applications by both training forms (599) made $41.98 \%$ of the total licensed scope (1427), that is, there were half as many people interested in mining as the HEIs assumed when determining the scope of a specialty license. The total number of people enrolled by both forms of education, both for the budget (238 people) and for the contract ( 45 people), was 283 people, which is $47.24 \%$ of the submitted applications and $19.83 \%$ of the licensed scope. This ratio indicates a five-fold increase in supply over demand.

The share of "Mining and quarrying" economic activity in GDP in 2017 was $5.9 \%$, which is the fifth largest value. In terms of the number of employed (220.5 thousand people), this type is inferior to 2017 only to type "Arts, sports, entertainment and recreation" (199.8 thousand people), whose share in the mentioned structure was $0.6 \%$ [4]. Logically, the number of HEIs providing training in the specialty "Mining" should be several times higher than the number of HEIs providing training in the specialties in the field of "Culture and Art". However, in contrast, the number of HEIs teaching art and culture is many times greater than the number of HEIs teaching mining. Therefore, if the total LS in Table 1 corresponds to the place and role of the mining industry in Ukrainian economy, the demand for mining knowledge and skills does not meet them.

The theory of rationality perfectly characterizes the behavior of entrants. In the light of epistemology, Domper K. sees a sense of rationality in a better cognitive way of deciding to achieve a goal by making choices (Domper K. K., 2009). An "immature" (or imperfect) system of views distorts perception, making it impossible to make a choice that would satisfy a person during his/her life.

According to Berger J. and Offe K., rational choice is the core of the analysis of economic phenomena in microeconomics (Berger J., Offe C., 1982). In this context, Richards M. interprets the choice of $\mathrm{HE}$ as an overall process in which hopes and desires are aligned with the real situation in the labor market (Richards M., 1973). For economists, according to Nickerson R., rationality means the optimal choice of specific criteria. As to HE, the author's view is acceptable. In his opinion, it is rational to consider the behavior of the person who makes the choice in favor of the best result (Nickerson R. S., 2008). The person chooses the specialty that will be most useful for him/her, and if he/she does not work in the specialty or neglects the level of education, then the choice should be considered irrational. The economic motives for obtaining HE prevail in the mind. Taking into account the theory of human capital, Paulsen M. believes that people analyze information about the dependence of earnings on the level of education in order to choose its optimal level (Paulsen M., 2001).

Kratt O. and Deieva L. have proved that rationality is an exceptional feature that allows us to evaluate the functioning

Table 1

Indicators characterizing the enrollment in "Mining" specialty according to ED $b$ and the forms of training based on CCSE in 2019

\begin{tabular}{|c|c|c|c|c|c|}
\hline HEI & Training form & LS & SA & EB & EC \\
\hline \multirow[t]{2}{*}{ Ivano-Frankivsk National Technical University of Oil and Gas (IFNTUOG) } & full-time & 120 & 98 & 42 & 1 \\
\hline & correspondence & 75 & 11 & - & 4 \\
\hline \multirow[t]{2}{*}{ National University "Yurii Kondratiuk Poltavska Politekhnika” (NUPP) } & full-time & 17 & 32 & 12 & - \\
\hline & correspondence & - & - & - & - \\
\hline \multirow[t]{2}{*}{ NTU of Ukraine “Kyiv Ihor Sikorskyi Polytechnic Institute” (NTUU KPI) } & full-time & 85 & 71 & 11 & 3 \\
\hline & correspondence & 60 & 1 & - & - \\
\hline \multirow[t]{2}{*}{ The National University of Water Industry and Nature Management (NUWINM) } & full-time & 39 & 31 & 11 & - \\
\hline & correspondence & 35 & 3 & 1 & - \\
\hline \multirow[t]{2}{*}{ East-Ukrainian Volodymyr Dal National University (EUNU) } & full-time & - & - & - & - \\
\hline & correspondence & - & - & - & - \\
\hline \multirow[t]{2}{*}{ National Technical University “Dnipro Polytechnic” (NTU DP) } & full-time & 300 & 132 & 52 & - \\
\hline & correspondence & 20 & 5 & 1 & - \\
\hline \multirow[t]{2}{*}{ SHE “Donetsk National Technical University” (DNTU) } & full-time & 80 & 38 & 20 & 1 \\
\hline & correspondence & 20 & 3 & - & 2 \\
\hline \multirow[t]{2}{*}{ State University “Zhytomyrska Politekhnika” (SUZP) } & full-time & 75 & 60 & 37 & - \\
\hline & correspondence & 12 & 5 & 2 & 1 \\
\hline \multirow[t]{2}{*}{ Kryvyi Rih National University (KNU) } & full-time & 255 & 96 & 44 & 32 \\
\hline & correspondence & 234 & 13 & 5 & 1 \\
\hline \multirow[t]{2}{*}{ Total by the training forms } & full-time & 971 & 558 & 229 & 37 \\
\hline & correspondence & 456 & 41 & 9 & 8 \\
\hline
\end{tabular}


of the HE system (Kratt O., Deieva L., 2008). The authors also came to the conclusion as to the use of the "rationality" characteristic to evaluate the development of HE within institutional theory (Kratt O., Deieva L., 2008). Thus, rationalism is a characteristic that emphasizes its cognitive orientation. In view of conceptualism, Stenmark M. characterizes rationality as a means of selecting useful methods for the realization of goals or preferences. Since, according to the author, it is a means of achieving both proven and doubtful goals, the rationality is a relative concept (Stenmark M., 1995). The relativity consists in the fact that the professional knowledge, skills and competencies acquired by the person are required for further sale in the labor market [5]. If a person is unable to sell his/her professional qualifications, the choice of the means can hardly be considered rational.

Richards M. defines the choice as a function of values of education and perception of chances of their realization in alternative professions (Richards M., 1973). Shaulska L. insists on constant monitoring of the professional and qualification structure of the employed people [6]. Thus, the rational choice of a professional education by a person is determined by the demand of the employer of the specialty and ED declared in the diploma. Therefore, the employers should influence the consumer's choice of professional educational services, as their professional and qualification needs should satisfy the quality of graduates of educational institutions. Therefore, solving the problem of person's rational choice of the future profession without mediocre and active involvement of employers is not feasible.

The essence of rationalism as a principle of action of the tool lies in the publicity of the determination of professional and qualification needs of the employer, which allows identifying the person's choice of specialty and ED. The publicity of the tool, first, provides comprehensive information to a certain range of people. In order to comply with this condition, the tool acquires the forms of the Directory of specialties required in the branch labor market (hereinafter - the Directory). A Directory as a form of information provides visualization of tools i.e. outline material forms. The boundaries of information provided in the Directory are defined by the term "branch", which means targeting the type of economic activity according to the CTEA.

The tool identifies qualitative and quantitative aspects of business needs for staffing that require clarification of the terms "staff", "staffing" and "staff unit".

The staff of the enterprise determines employer-staffing needs. Although the staff and staffing are essential attributes of an enterprise, an applicable law does not stipulate them. According to the common meaning, the staff is a permanent or fixed on a certain date list of the personnel of the enterprise with an indication of positions and other parameters. Staffing is a document that determines the list of the personnel of the enterprise with the indication of posts and salaries. The terms are almost identical, but if the staffing list is always a document, the staff is not necessarily a document; even on the contrary, it is not a document, but real people. For example, if an enterprise employs 10 people on a permanent basis according to a labor contract, there is reason to believe that the staff of that enterprise is 10 employees. In addition, no documentary confirmation is required in the form of a staffing list, the term "staff unit" means a position or work unit provided for by staff or staffing. As to the staff, the term "number of staff units" means the number of employees who actually occupy a certain position, and as to the staffing list - the number of units of one position provided for in the document. It is incorrect to claim that the enterprise has ten staff units. It has ten employees who make up its staff or work in full-time staffing positions. The number of staff units may be greater or fewer, depending on the number stipulated by the staffing list. The term "staff unit" in the analysis of the profession and qualification structure of the staff refers to the number of employees holding the posi- tion. In characterizing the needs of employers, this term means the need for an employee to occupy a position, i.e., both satisfied and unmet demand.

The tool is based on the impossibility of forcing a business to cooperate with the individual and the HEI. Employers need to be aware of the involvement and responsibility for the person's choosing the right specialty and educational degree [7]. Bussmann S. and Seyda S. argue that for Germany, the professionalism of staff is a key element of the innovation strength and competitiveness of the economy. Shortage of skilled workers in the labor market in the short term threatens to disrupt delivery times, and in the medium and long term, it has serious consequences [1]. When positioning a business tool, one should be clear about what information, in what form, and most importantly, what benefit an employer will have from disclosing staffing needs. When answering the first question, one should bear in mind that when choosing a profession, a young person and his or her environment expect to find application of the knowledge declared in the diploma of education. Therefore, the purpose of the tool is to identify the demand parameters of entrants with vocational training needs of employers [8]. The latter are formally determined in job descriptions containing requirements for the applicant's specialty and ED. As for the ED, it should be noted that the ED $s w$ does not belong to the HE, but given the large proportion of persons with HE who work as skilled workers, this ED should be in the Directory.

To find out if a business can provide such information, you need to have an idea of the staffing needs of the enterprise. Given that specialists with diplomas occupy positions that do not require any qualifications, an "Unskilled workers" (USW) segment of the in-company labor market is presented in the analysis of the staffing needs of employers.

The personnel of the Poltava Mining and Processing Plant (hereinafter referred to as MPP) ore shop was taken as the operational sphere of the research. The staff of the shop is 703 staff units. Table 2 shows the number of posts and staff units of MPP by ED.

The data in Table 2 prove that the posts and the ED determine the qualitative aspect of the needs of MPP, and staff units - the quantitative one. In terms of the number of staff units, the percentage of the needs for ED $m$ at MPP was higher than the percentage of ED $b$ by only $1.00 \%$. By the number of posts, the difference between the percentage of segments was much larger: ED $m>$ ED $b$ by 1.79 times. Therefore, employers prefer specialists with complete HE, which should be taken into account by bachelors when deciding whether to continue their studies in the magistracy. More pronounced is the ratio of segments $\operatorname{ED} b$ and $\operatorname{ED} j s$. By the number of staff units, the percentage of $\operatorname{ED} b$ exceeds the percentage of ED $j s$ by 14.96 times. By the number of posts, the percentage of ED $b$ exceeds the percentage of ED $j s$ by 9.51 times.

It is noteworthy that the position of "Storekeeper" at the MPP belongs to the segment of ED $s w$, since in the training department (hereinafter - TD) of MPP there is such a specialty, and therefore, this profession is not so easy. The survey selected the production shop of the MPP, in which the demand for skilled workers dominated. Table 3 contains nine most required specialties by the number of staff units.

Table 2

The number of posts and staff units at the enterprise by ED

\begin{tabular}{|l|l|c|c|c|c|c|c|}
\hline \multirow{2}{*}{$\begin{array}{c}\text { Enterprise and its } \\
\text { characteristics }\end{array}$} & \multicolumn{5}{|c|}{ Education degree } & \multirow{2}{*}{ Total } \\
\cline { 2 - 8 } & $u s w$ & $s w$ & $j s$ & $b$ & $m$ & \\
\hline \multirow{2}{*}{ Scope } & Posts & 1 & 29 & 2 & 19 & 34 & 85 \\
\cline { 2 - 8 } & Units & 2 & 580 & 4 & 60 & 67 & 703 \\
\hline \multirow{2}{*}{ Percentage } & Posts & 1.18 & 34.12 & 2.35 & 22.35 & 40.00 & 100.0 \\
\cline { 2 - 7 } & Units & 0.28 & 81.08 & 0.57 & 8.53 & 9.53 & 100.0 \\
\hline
\end{tabular}


Table 3

Characteristics of MPP's significant needs in specialists with ED sw

\begin{tabular}{|l|c|c|}
\hline \multicolumn{1}{|c|}{ Specialty (profession) } & $\begin{array}{c}\text { Number of } \\
\text { posts }\end{array}$ & $\begin{array}{c}\text { Number of } \\
\text { staff units }\end{array}$ \\
\hline Shovel man & 2 & 194 \\
\hline Drilling rig operator & 2 & 110 \\
\hline Electrician & 2 & 85 \\
\hline Metal worker & 3 & 67 \\
\hline Electrical gas welder & 3 & 34 \\
\hline Pumping unit operator & 2 & 18 \\
\hline Miner & 1 & 18 \\
\hline Operator of computers and calculators & 1 & 15 \\
\hline Underground electrician & 1 & 6 \\
\hline
\end{tabular}

According to Table 3, the most numerous of these positions was the "Quarry shovel man" - 98 staff units. The second place was occupied by the position of "Quarry shovel man assistant" - 96 units. Both positions required the specialty "Shovel man" in accordance with the job descriptions, and, therefore, the importance of 194 skilled workers with this specialty is significant for MPP. All shovel men had a relevant specialty according to the diploma, and only one worker had a different specialty among the shovel men assistants. Assuming that each shovel man must have an assistant, at the time of the survey at the MPP there were two vacancies for the position of "Quarry shovel man assistant". The very availability of vacancies proves that a person who had ED $b$ with a specialty "Mining Engineer" worked in this position. Thus, the need for shovel men was 196 units. In addition, there is no absolute certainty that all staff units in the positions of a "Quarry shovel man assistant" are $100 \%$ filled, and therefore the number of vacancies in the "Quarry shovel man" position may be greater. The presence of at least two vacancies makes it possible to consider the need, first, to increase the level of openness of information on the availability of vacancies, and, secondly, the availability of personnel reserve in the specialty "Shovel man".

The "Quarry drilling rig operator" position is filled with 52 staff units and the "Quarry drilling rig operator assistant" position is filled with 58 staff units. Applying assumptions about the equality of staff units in both positions, we can conclude that there are at least six vacancies in the position of "Drilling rig operator". Professional education of 50 operators meets the requirements of the position, the professional education of one operator corresponds partially (related specialties), and another - does not meet them. Appointment of a skilled worker with a specialty of a "Shovel man" to the post of a "Quarry drilling rig operator" and a junior specialist with the specialty of a "Mining technician" confirms the lack of specialists in the relevant profile. In addition to 56 people with similar education requirements, a shovel man and mining electromechanical technician also work in the position of "Quarry drilling rig operator assistant", which makes it possible to assume vacancies for this position as people who have not been trained in the training complex of MPP are admitted to these positions.

MPP has a license of the Ministry of Education and Science of Ukraine to provide educational services by educational institutions related to obtaining vocational education at the level of qualification requirements for vocational training, retraining, advanced training of specialty (profession) and licensed scopes of admission. Thus, the MPP TD, which provided vocational training, retraining and advanced training, acted as a full-fledged educational institution. Thus, 52 of the 98 people who held the position of "Quarry shovel man", 38 of
96 people who held the position of "Quarry shovel man assistant", 30 of the 52 who held the position of "Quarry drilling rig operator", 29 of the 58 people holding the position of "Quarry drilling rig operator assistant" received professional training at the MPP TD, which enabled them to occupy the relevant position. This means that five people who have occupied these positions but have not received professional education at MPP will probably fill the gaps in their professional education in the enterprise TD.

The position of the "Electrician for the repair of equipment in the quarry on duty" requires the specialty of the "Electrician". Therefore, 50 out of 80 people in this position obtained the specialization in TD, and the rest - in VTEE. The presence of such a specialty also requires the post of "Electrician for the repair of equipment on duty", which was occupied by five staff units. Four employees received the specialization in TD and one at the VTEE. By the number of staff units, the specialty "Electrician" is the third in the shop.

The positions of "Metalworker" and "Quarry metalworker" provided for the availability of a specialty of a "Metalworker". While there were five staff units for the first position, there were 57 staff units for the second position. The diploma specialty of all 52 skilled employees who held these positions was in full compliance with the requirements of the position, and 39 of them were educated in TD.

Thus, 327 people in the positions requiring ED $s w$ obtained their specialty at TD, which makes $57.27 \%$ of all the skilled workers in the shop. Thus, TD successfully competes with VTEE, colleges and technical schools. It should be noted that 250 people out of 339 , who had several education degrees and occupied blue-collar positions, were educated in TD, that is, the absolute majority of people met the educational need for a specific attainable purpose - position. In this situation, the level of pragmatism in their behavior is significant because, maybe for the first time in their lives, they realize why they need professional knowledge, and skills. In addition, out of 238 people who had a specialty in ED sw, 77 people were educated in the TD, that is, most job applicants sought traditional ways of getting a profession. Thus, increasing pragmatism level admits breaking the stereotypes through informational influences on personality consciousness.

Table 4 contains characteristics of the enterprise need for employees with a specialty by ED $m$.

According to the information in Table 4, MPP had considerable needs for mining engineers as well as for mine surveyors and geologists. MPP needed seven specialties, which is 4.86 times less than the number of positions and 9.57 times less than the number of staff units. Therefore, units measure the needs for specialists with full higher education within the structural unit. It suggests that within the enterprise their number will not exceed several scores, since it is a single technological cycle.

Table 4

Characteristics of the enterprise need for employees with a specialty by ED $m$

\begin{tabular}{|l|c|c|}
\hline Specialty & Number of positions & Number of staff units \\
\hline Mining engineer & 19 & 37 \\
\hline Geologist & 5 & 7 \\
\hline Mine surveyor & 4 & 16 \\
\hline Mechanical engineer & 3 & 3 \\
\hline Hydrogeologist & 1 & 1 \\
\hline Electrical engineer & 1 & 1 \\
\hline Power engineer & 1 & 1 \\
\hline
\end{tabular}


For each ED, the general need for employees in certain specialties is much smaller than the number of positions and, moreover, the staff units. This allows us to argue that the complexity of forming a list of specialties in the industry dimension is quite acceptable to perform.

The ratio of ED specialties indicates the existence of proportions between levels. At MPP there are more specialties of ED $s w$ than specialties of every other ED separately. The number of specialties for ED $m$ exceeds the number of $\operatorname{ED} b$, which exceeds the number of ED $j s$.

There are a number of positions in MPP that belong to Section 1 "Occupations common to all types of economic activity" of the State list of professions for the training of skilled workers in vocational schools [9]. In addition to MPP, in Kremenchuk region there are quarries for the extraction of crushed stone, and also the issue of construction of Bilanivsky MPP is discussed, which confirms the unification of specialties in section 3 "Occupations common to the mining industry (sections 10,12) and construction (section 45, subclass 45.21.2) Construction of bridges, overpasses, tunnels and subways".

Therefore, the above arguments point to the possibility of creating a Directory that would contain qualitative (name of specialties) and quantitative (the number of staff units) aspects of real demand in the branch dimension. The absence of mentioning the carrier of the needs will allow putting all enterprises without exception in the same conditions as to the further employment. The possible emergence of the dynamics of staff units will make it possible to fix trends in demand. The absence of a service provider in the Directory ensures the same conditions for consumer choice.

The format of the Directory should be as consistent as possible with the parameters of the consumer choice. Choosing a professional future, the person, apart from the specialty, also determines ED, and therefore ED should systematize the needs of consumers. When choosing a profession, consumers of educational services are guided by the list of specialties [2], which is part of the educational standard. However, a circumstance prevents the formalization of consumer choice of specialty. Modern forms of personnel accounting at the enterprise provide columns that contain information about the employee's education. In these columns, MPP shows the educational institution, the name and even the code of the specialty, as well as the qualification. Besides, there is no column indicating the required specialty, and if any, information does not meet the educational standard. In order to meet consumer requirements in the format of the Directory, the employers should put personnel accounting in good order with the educational standard.

The initiative to create the Directory should belong to the All-Ukrainian Association of Region Employers of Mining Enterprises "Federation of Mining Employers of Ukraine" (hereinafter - the Federation), which was created in 2007 in accordance with the Laws of Ukraine "On Employers' Organizations", "On Association of Employers". The Federation is also created to coordinate and consolidate the actions of its members in the field of social and labor relations. The creation of the Directory is a realization of the main activity of the Federation - "balancing the demand and supply of labor, preventing mass unemployment through promoting the creation of new jobs, ensuring a rational structure of employment" [10].

Conclusions. Thus, the above allows us to draw conclusions. First, the low level of educational pragmatism in the behavior of consumers of educational services is explained by the lack of professional experience. It is possible to compensate for this shortcoming by creating a tool of a person's choice of the profession based on the principle of rationality. Rationality as a principle of operation of the choice tool provides for the employers' disclosure of their professional and qualification needs, which allows the entrants to formulate goals and choose methods for their realization. Formally, the needs of employers in the local labor market are presented in the Directory of specialties. Second, when choosing a professional future, applicants focus on specialties presented in educational standards rather than on positions. Identification of educational needs of the individual and the staffing needs of employers revealed multiple excess of the number of positions and staff units over the number of specialties. This fact is the main proof of the possibility of establishing a Directory. The information provided in the Directory should be systematized by ED and be impersonal as to employers and HEI. The employer independently determines what staffing needs to be made public. Branch employers' associations should initiate the creation of the Directory. Third, content regarding the qualitative (specialty) and quantitative (staff units) aspects of the impersonal personnel needs of the mining industry should be recognized as a scientific and practical basis for the development of $\mathrm{HE}$ in the context of consumer choice. It is the content that enables employers to influence the person's rational choice of the most useful for the future employment of vocational qualification parameters of $\mathrm{HE}$ in the absence of professional experience, which will significantly improve the professional orientation of the person.

\section{References.}

1. Bußmann, S., \& Seyda, S. (2014). Fachkräfteengpässe in Unternehmen: Die Altersstruktur in Engpassberufen. IW Medien $\mathrm{GmbH}$.

2. On approving the list of branches of knowledge and specialties for which higher education applicants are trained: Resolution No. 266 of the Cabinet of Ministers of 29.04.2015. Official Bulletin of Ukraine. 2015. No. 38. cl. 1147. Retrieved from https://www.kmu.gov.ua/npas/248149695.

3. Vstup.OSVITA.UA (n.d.). Vstup.OSVITA.UA. Data obtained from EDEBO (23.03.2020). Retrieved from https://vstup.osvita.ua/.

4. Verner, I.E. (Ed.). (2018). Statistical yearbook of Ukraine, 2018. The State service of statistics of Ukraine. Zhytomyr: Company "Bruk-Drul”, 2019. Retrieved from http://www.ukrstat. gov.ua/druk/publicat/kat_u/2019/zb/11/zb_yearbook_2018. pdf.

5. Trunina, I., \& Khovrak, I. (2019). Harmonization of the Interests of Employers and Institutions of Higher Education as a Basis for the Sustainable Regional Development. 2019 IEEE International Conference on Modern Electrical and Energy Systems (MEES), (pp. 398-401). https://doi.org/10.1109/ mees.2019.8896688.

6. Shaulska, L. V. (2015). New features of employment field and the prospects of its regulation. The theoretical and practical aspects of economy and intellectual property: collection of papers, 2(12), 120-128.

7. Zagirniak, D., Perevozniuk, V., \& Kratt, O. (2019). Rationalization of Professional Orientation of a Person According to the Needs of the Business. 2019 IEEE International Conference on Modern Electrical and Energy Systems (MEES), (pp. 422-425). https://doi.org/10.1109/mees.2019.8896639.

8. Zagirniak, D., Kratt, O., \& Trunina, I. (2017). The assessment of the provision of the industry with specialists in electrical engineering. 2017 International Conference on Modern Electrical and Energy Systems (MEES), (pp. 356-359). https:// doi.org/10.1109/mees.2017.8248931.

9. On the approval of the State list of professions for which skilled workers are trained in vocational technical education establishments: Resolution No. 1117 of the Cabinet of Ministers of Ukraine of 11.09.2007. Official Bulletin of Ukraine, 70. cl. 2656. Retrieved from https://zakon.rada.gov.ua/laws/ show/1117-2007-\%D0\%BF.

10. Statute of All-Ukrainian Association of Regional Employers Organization of Mining Enterprises "Federation of Employers of Miners of Ukraine” (n.d.). Retrieved from http://frgu.org. ua/?page id=341. 


\section{Раціоналізація вибору професійної освіти в контексті потреб бізнес-середовища}

\section{Д. М. Загірняк, О.А. Кратт, М. В. Загірняк}

Кременчуцький національний університет імені Михайла Остроградського, м. Кременчук, Україна, е-mail: deniszagirniak@gmail.com; mzagirn@kdu.edu.ua

Мета. Раціоналізація вибору особою вищої освіти щодо кадрових потреб галузевого бізнес-середовища на підставі визначення кількості зайнятих посад і штатних одиниць за освітнім ступенем у галузевому довіднику спеціальностей.

Методика. Метод раціонального вибору потенційним споживачем освітніх послуг майбутньої професії (на прикладі спеціальності «Гірництво»), заснований на параметризації професійно-кваліфікаційних потреб добувних підприємств як суб'єктів галузевого бізнес-середовища.

Результати. Сформовані методичні рекомендації щодо професійної орієнтації особи в контексті потреб галузевого бізнес-середовища (підприємств добувної промисловості). Низький рівень освітнього прагматизму в поведінці споживачів освітніх послуг пояснюється відсутністю професійного досвіду. Вибираючи професію, абітурієнти орієнтуються на спеціальності, запропоновані в освітніх стандартах, а не на потреби роботодавців. Зокрема, штатний розклад видобувних підприємств відбиває якісний і кількісний склад професійно-кваліфікаційних потреб роботодавців, зафіксованих у посадових інструкціях. Методичні рекомендації мають форму Довідника, що містить якісні (спеціальність) і кількісні (штатні одиниці) аспекти знеособлених кадрових потреб добувної промисловості. Ці дані дозволяють роботодавцям впливати на споживчі вподобання абітурієнтів з урахуванням майбутнього працевлаштування, професійнокваліфікаційних характеристик. Це, з одного боку, вельми поліпшить професійну орієнтацію особи, а, з іншого, оприлюднить кадрові потреби підприємств добувної галузі як базису вітчизняного бізнес-середовища.

Наукова новизна. Раціоналізація вибору особою вищої освіти й найбільш корисної, щодо майбутнього працевлаштування, професії завдяки оприлюдненню якісних і кількісних аспектів кадрових потреб підприємств у галузевому Довіднику спеціальностей.

Практична значимість. Публічна консолідація кадрових потреб підприємств добувної галузі у Довіднику спеціальностей, що затребувані на галузевому ринку праці, дозволяє роботодавцям дієво впливати на вибір потенційними споживачами професійних освітніх послуг спеціальності «Гірництво».

Ключові слова: вища освіта, гірництво, добувна галузь, посада, потреби роботодавців

\section{Рационализация выбора профессионального образования в контексте потребностей бизнес-среды}

Кременчугский национальный университет имени Михаила Остроградского, г. Кременчуг, Украина, e-mail: deniszagirniak@gmail.com; mzagirn@kdu.edu.ua

Цель. Рационализация выбора человеком высшего образования относительно кадровых потребностей отраслевой бизнес-среды на основании определения количества занятых должностей и штатных единиц по образовательным степеням в отраслевом справочнике специальностей.

Методика. Метод рационального выбора потенциальным потребителем образовательных профессиональных услуг будущей профессии (на примере специальности «Горное дело»), основанный на параметризации профессионально-квалификационных потребностей добывающих предприятий как субъектов отраслевой бизнессреды.

Результаты. Сформированы методические рекомендации по профессиональной ориентации человека в контексте потребностей отраслевой бизнес-среды (предприятий добываюшей промышленности). Низкий уровень образовательного прагматизма в поведении потребителей образовательных услуг объясняется отсутствием профессионального опыта. Выбирая профессию, абитуриенты ориентируются на специальности, предложенные в образовательных стандартах, а не на потребности работодателей. В частности, штатное расписание добывающих предприятий отражает качественный и количественный состав профессиональноквалификационных потребностей работодателей, зафиксированных в должностных инструкциях. Методические рекомендации имеют форму Справочника, который содержит качественные (специальность) и количественные (штатные единицы) аспекты обезличенных кадровых потребностей добывающей промышленности. Эти данные позволяют работодателям влиять на потребительские предпочтения абитуриентов с учетом будущего трудоустройства, профессионально-квалификационных характеристик. Это, с одной стороны, весьма улучшит профессиональную ориентацию лица, а с другой, обнародует кадровые потребности предприятий добывающей отрасли как базиса отечественной бизнес-среды.

Научная новизна. Рационализация выбора лицом высшего образования и наиболее полезной, относительно будущего трудоустройства, профессии благодаря обнародованию качественных и количественных аспектов кадровых потребностей предприятий в отраслевом Справочнике специальностей.

Практическая значимость. Публичная консолидация кадровых потребностей предприятий добывающей отрасли в Справочнике специальностей, которые востребованы на отраслевом рынке труда, позволяет работодателям действенно влиять на выбор потенциальными потребителями профессиональных образовательных услуг специальности «Горное дело».

Ключевые слова: высшее образование, горное дело, добывающая отрасль, потребности работодателей

Recommended for publication by V.V. Babichenko, Doctor of Economic Sciences. The manuscript was submitted 22.02.20. 